\title{
MASYARAKAT MEMANDANG GRATIFIKASI DALAM TINDAK PIDANA KORUPSI
}

\author{
Elisabeth Bethesda \\ Program Studi S2 Ilmu Hukum, Fakultas Hukum, Universitas Indonesia \\ E-mail : elisabethesda@gmail.com
}

\begin{abstract}
ABSTRAK
Hukum yang ada di tengah masyarakat tumbuh dan berkembang bersama-sama dengan masyarakat itu sendiri yang dilandasi oleh adanya kesadaran masyarakat oleh karena kepentingan individu dan kepentingan masyarakat yang tidak ingin terganggu. Agar hukum itu bermanfaat bagi masyarakat, maka ketentuan dalam hukum disesuaikan dengan hukum yang hidup di dalam masyarakat (living law). Hukum yang disepakati selain memuat pencegahan untuk tidak terjadi perilaku yang melanggar norma-norma atau kaedah-kaedah. Gratifikasi sebagai suatu yang a-moral di Undang Undang Tindak Pidana Korupsi, bahkan menyamakan gratifikasi dengan suap. Praktik gratifikasi dinyatakan harus diberantas, meskipun tidak sepenuhnya dapat diterima oleh masyarakat karena pemberian dan penerimaan dianggap sebagai norma baik bahkan dilestarikan. Pemberian atau penerimaan sesuatu antar pihak pemberi dan penerima menjadi 'masalah' ketika perbuatan pemberian dan penerimaan itu dinyatakan suatu perbuatan melanggar hukum pidana.
\end{abstract}

Kata Kunci : Gratifikasi, Masyarakat, Tindak Pidana Korupsi.

\section{ABSTRACT}

Law that exist in community develops alongside the community itself and is based on community awareness in order to avoid individual and community interests disorders. Further, to make the law beneficial to the community, then the provisions of law are adjusted to the living law. The agreed law contains precautions to avoid violation of norms or customs. Gratification as an immoral act in the Anti-Corruption Law; it even compares gratification with bribery. However, gratification must be eradicated although the community views it as a good norm and need to be preserved. Giving or receiving gifts among the giver and the recipient becomes a 'problem' when the act of giving and receiving is stated as an act of violating the criminal law.

Keywords: Gratification, Community, Criminal Acts of Corruption.

\section{Pendahuluan}

Budaya bangsa Indonesia sejak dahulu kala secara turun temurun telah berjalan suatu kebiasaan tolong menolong atau saling membantu dalam kehidupan masyarakat yang dilakukan melalui banyak cara, diantaranya adalah memberi dan menerima sesuatu, namun tidak terbatas dalam hal materil. Ditolong tidak karena ada permintaan untuk ditolong atau dibantu bukan karena ada permintaan untuk dibantu, tetapi karena didasarkan adanya kesadaran individu yang hidup bergaul atau berinteraksi bahwa hidup tidak dapat sendiri melainkan hidup ditengahtengah masyarakat lainnya. 
Kesadaran saling menolong atau membantu merupakan kebiasaan yang diikuti dari yang dilakukan oleh masyarakat sebelumnya, dan hal itu merupakan suatu hal yang baik. Hal tolong menolong atau saling bantu yang demikian menjadi suatu ciri khas bangsa Indonesia, yang kemudian dilestarikan secara turun temurun. Ciri khas itu mulai tergerus seiring dengan perkembangan disegala bidang terutama bagi masyarakat di wilayah perkotaan, namun bagi masyarakat di wilayah pedesaan masih dapat ditemukan dengan konkrit. Bahkan tolong menolong atau saling bantu bukan saja hanya diartikan sebagai suatu kebiasaan, namun secara filosoif bahwa 'meminta tetapi ditolak merupakan hal yang sakit, dan lebih sakit apabila diberi tetapi ditolak'. 'Meminta tapi ditolak' merupakan hal yang umum terjadi, namun 'diberi tapi ditolak' merupakan hal yang jarang terjadi. Logan Siagain mengatakan pemberian memang sudah menjadi kesatuan dalam sukusuku di Indonesia. Siagian menuturkan bahwa ada pepatah dalam bahasa Batak "hansit mulak manjalo, hansitan mulak mangalean", terjemahan langsungya adalah "Sakit ditolak (ketika kita) meminta, tapi lebih sakit ditolak (ketika kita) memberi." Pemberian yang ditolak tidak jarang menjadi suatu masalah besar, bahkan tidak jarang juga berujung pada perkelahian berdarah, dan masalah itu terbawa hingga pada keturunan pihak terkait (https://www.hukumonline.com). Permintaan atau pertolongan tidak terbatas dalam hal-hal besar, namun sekedar kehadiran seseorangpun dalam suatu acara atau kegiatan orang lain adalah merupakan salah satu bentuk tolong menolong atau bantu membantu dalam pengertian luas.

Di sektor swasta di Amerika Serikat, bahwa budaya memberi uang tips sudah menjadi hukum tidak tertulis, meskipun pemberian atau tidak memberi tidak diancam dengan suatu pidana. Sedangkan budaya Asia Timur berbeda dengan budaya Amerika Serikat, seperti Jepang dan Korea Selatan bahwa masyarakatnya menolak pemberian yang bukan haknya. Kedua budaya (Amerika dan Asia Timur) sama-sama dapat dikatakan 'bangga', di Amerika Serikat bangga dengan tips yang diterima karena dianggap pelayananan yang diberikan cukup memuaskan, sedangkan di Asia Timur bangga karena menolak yang bukan haknya. Tampaknya cukup beralasan dengan adagium yang berkembang 'tidak boleh menolak rezeki dari Tuhan, sedangkan pemberi adalah perpanjangan tangan Tuhan'. Hal ini semakin memperkuat akan budaya bangsa Indonesia yang saling tolong. Disisi lain, kebiasaan memberi dalam budaya bangsa Indonesia, baik karena kebiasaan dalam adat istiadat bahkan dalam ruang lingkup keagamaan menjadi alasan pembenar untuk tetap berlakunya saling memberi, meskipun berhubungan dengan suatu pelayanan publik yang memiliki kepentingan lain selain kebiasaan budaya bangsa.

Dalam buku Pedoman Pengendalian Gratifikasi yang diterbitkan KPK tahun 2015 bahwa gratifikasi dianggap sebagai akar korupsi, oleh karena itu praktik gratifikasi harus diberantas (Pedoman Pengendalian Gratifikasi). Namun Syed Hussei Alatas memotret 
pemberian hadiah tersebut dalam bukunya Korupsi, Sifat, Sebab dan Fungsi (Jakarta, LP3ES; 1987), menurutnya, praktik pemberian hadiah tidak serta merta dapat dipandang sebagai faktor penyebab korupsi. Hal seperti itu telah hidup cukup lama, tidak saja di Indonesia dan negara-negara Asia namun juga negara-negara barat. Akan tetapi, praktik yang bersumber dari pranata tradisional tersebut kemudian ditunggangi kepentingan di luar aspek hubungan emosional pribadi dan sosial kemasyarakatan. Dalam buku Sosiologi Korupsi, Alatas menulis: "hal menarik yang diperbuat di sini adalah perbedaan antara kesewenang-wenangan dan praktek yang layak dari pranata tradisional pemberian hadiah. Bila pembedaan ini sudah diperbuat, tidak sulit membayangkan bagaimana korupsi menjalar. Akan tetapi, kita harus mengkaji makna kebiasaan pemberian sebagai suatu sumber kesewenang-wenangan dalam jaringan kausal korupsi, mengingat fakta bahwa praktek-praktek lain yang disetujui oleh masyarakat telah dijangkiti oleh korupsi" (Alatas, 1983: 56). Demikian juga Thamrin Amal Tamagola (2009) memandang hadiah sebagai sesuatu yang tidak saja lumrah dalam setiap masyarakat, tetapi juga berperan sangat penting sebagai „kohesi sosial" dalam suatu masyarakat maupun antarmasyarakat/marga/puak bahkan antar bangsa. Senada dengan itu, Kastorius Sinaga (2009) memberikan perspektif sosiologis mengenai gratifikasi yang mengungkapkan bahwa konsepsi gratifikasi bersifat luas dan elementer di dalam kehidupan kemasyarakatan. Jika memberi dan menerima hadiah ditempatkan dalam konteks hubungan sosial maka praktek tersebut bersifat netral. Akan tetapi, jika terdapat hubungan kekuasaan, makna gratifikasi menjadi tidak netral lagi.

Merujuk pada data Global Corruption Barometer (GCB) Tahun 2013 yang dirilis Transparency International, untuk mendapatkan pelayanan publik $71 \%$ responden mengatakan mengeluarkan "uang pelicin" agar dapat mengakses pelayanan publik. Empat latar belakang utama pembayaran uang pelicin tersebut adalah: satu-satunya cara mendapatkan pelayanan $(11 \%)$; mempercepat pengurusan (71\%); mendapatkan pelayanan lebih murah (6\%); sebagai hadiah atau ucapan terima kasih (13\%) (http://kpk.go.id). Data tersebut menunjuk pada pelayanan di sektor publik sebagai gratifikasi yang membebani pihak swasta, meskipun gratifikasi itu tidak selalu datang lebih dahulu dari pelayan publik, namun berkaitan erat dengan kepentingan pihak swasta, yang pada akhirnya terjadi saling memberi dan saling menguntungkan. Gratifikasi itupun dijadikan sebagai biaya tambahan dalam proses produksi atau pekerjaan yang pada muaranya berimplikasi pada tanggungan konsumen sebagai pengguna akhir.

Pemahaman ragam tentang gratifikasi yang diidentikkan sebagai suatu yang a-moral, bahkan menyamakan gratifikasi dengan suap. Oleh sebab itu praktik gratifikasi harus diberantas, meskipun tidak sepenuhnya dapat diterima oleh masyarakat karena pemberian dan penerimaan dianggap sebagai norma baik bahkan dilestarikan. Pemberian atau penerimaan sesuatu antar pihak pemberi dan penerima menjadi 
'masalah' ketika perbuatan pemberian dan penerimaan itu dinyatakan suatu perbuatan melanggar hukum pidana.

\section{Rumusan Masalah.}

Perbuatan memberi dan menerima sebagaimana diuraikan di atas yang dianggap sebagai suatu pelanggaran hukum pidana, yakni memberi atau menerima; uang, barang, rabat (discount), komisi, pinjaman tanpa bunga, tiket perjalanan, fasilitas penginapan, perjalanan wisata, pengobatan cumacuma, dan fsilitas lainnya, maka rumusan masalah yang diangkat adalah "Sejauhmana Masyarakat Memandang Gratifikasi Sebagai Tindak Pidana Korupsi ?"

\section{Manfaat Penelitian}

1. Manfaat praktis

a. Tulisan ini bermanfaat bagi Penyidik tindak pidana korupsi dalam menetapkan tersangka sesuai dengan hukum acara pidana dan ketentuan peraturan perundangundangan terkait dengan tindak pidana korupsi gratifikasi.

b. Tulisan ini bermanfaat bagi masyarakat dalam arti luas, terutama bagi tersangka guna mengetahui lebih jauh mengenai proses dan prosedur penetapan tersangka tindak pidana korupsi dalam rangka mencegah terjadinya kesewenangwenangan aparat penegak hukum.

c. Tulisan ini dapat bermanfaat bagi Hakim dalam memeriksa penetapan tersangka dalam tindak pidana korupsi gratifikasi

d. Tulisan ini dapat bermanfaat bagi peneliti sendiri dalam rangka mengembangkan ilmu pengetahuan.

2. Manfaat Teoritis a. Tulisan ini diharapkan dapat berguna sebagai bahan untuk pengembangan wawasan dan kajian lebih lanjut di masa datang, terutama bagi yang ingin memperdalam masalah penetapan tersangka sebagai objek praperadilan dalam tindak pidana korupsi.

b. Tulisan ini dapat bermanfaat untuk melengkapi tugas-tugas dalam memenuhi syarat sebagai salah satu kewajiban pada akhir perkuliahan sosiologi hukum pidana Universitas Indonesia.

\section{Tinjauan Pustaka}

\section{Kerangka Teori.}

Mengingat ini dibatasi pada pembahasan putusan praperadilan mengenai penetapan tersangka dalam tindak pidana korupsi ditinjau dari sisi yuridis, maka dalam tinjauan pustaka pada sub bab kerangka teoriini memuat teori-teori, azas hukum, prinsip-prinsip, aturanaturan, pendapat-pendapat, proposisi dan lain-lain, yang relevan sebagai landasan penelitian, diantaranya adalah :

a. Hak konstitusional setiap orang.

Bahwa setiap orang berhak atas pengakuan, jaminan, perlindungan dan kepastian hukum yang adil serta perlakuan yang sama di hadapan hukum, sebagaimana dinyatakan dalam Pasal 28 D ayat (1) UUD 1945. Negara Republik Indonesia telah meratifikasi Kovenan Internasional tentang Hak-Hak Sipil dan Politik (International Covenant on Civil and Political Right) melalui UndangUndang Nomor : 12 Tahun 2005, merupakan salah satu instrumen internasional yang berisi mengenai pengukuhan pokok-pokok hak asasi manusia. Dalam ketentuan yang telah 
diratifikasi tersebut, negara berjanji untuk memberikan jaminan guna melakukan pemulihan terhadap seseorang yang hak-haknya telah dilanggar dalam kaitannya dengan pelaksanaan tugas institusi negara atau penegak hukum.

\section{b. Perlindungan hukum.}

Abad ke-13, Raja John di Inggris memimpin negaranya dengan sistem monarki absolut, telah bertindak kelewat batas atas tanah milik orangorang yang berpengaruh, termasuk masalah-masalah lain, sehingga terjadi perselisihan. Para baron (bangsawan) menuntut Raja John untuk memberikan hak-hak tertentu, mengharuskan raja membatalkan beberapa hak dan menghargai prosedur legal serta keinginan raja dibatasi oleh hukum. Dari berbagai peristiwaitu, lahirlah Magna Carta(Piagam Perjanjian) sebagai simbol dan seruan melawan penindasan, yang selanjutnya dipahami sebagai perlindungan atas kebebasan yang terancam. Magna Cartamerupakan langkah awal dalam proses sejarah panjang menuju pembuatan hukum konstitusional. Setelahnya, lahir berbagai undangundang seperti persamaan hak dimuka hukum (Habeas Corpus Act), undang-undang yang mengatur tentang kebebasan (Bill of Rights), dan lain-lain.

\section{Kerangka Konsep}

Kerangka konseptual adalah kerangka yang menggambarkan hubungan antara konsep-konsep khusus yang akan diteliti, baik dalam penelitian hukum normatif maupun empiris. Biasanya telah merumuskan dalam definisi-definisi tertentu atau telah menjalankan lebih lanjut dari konsep tertentu (Soekanto. 2007).
Kerangka konseptual merupakan kerangka yang menghubungkan atau menggambarkan konsep-konsep khusus yang merupakan kumpulan dari arti yang berkaitan dengan istilah. $^{12}$ Upaya memudahkan pengertian yang terkandung dalam kalimat judul penelitian ini, maka penulis dalam konseptual ini menguraikan pengertian-pengertian yang berhubungan erat dengan penulisan ini, maka akan dijelaskan beberapa istilah yang dipakai, yaitu sebagai berikut :

1.

Analisis adalah suatu proses berfikir manusia tentang sesuatu kejadian atau pristiwa untuk memberikan suatu jawaban atas kejadian atau pristiwa tersebut.

2.

Pertanggungjaw aban pidana adalah sesuatu perbuatan pidana yang harus dipertanggungjawabkan atas perbuatan yang dilakukan.

3.

Putusan

pengadilan adalah pernyataan hakim yang diucapkan dalam sidang pengadilan terbuka, yang dapat berupa pemidanaan atau bebas atau lepas dari segala tuntutan hukum dalam hal serta menurut cara yang diatur dalam undang-undang.

a. Tindak pidana Gratifikasi adalah suatu pemberian dalam arti luas yakni meliputi pemberian uang, barang, rabat (discount), komisi, pinjaman tanpa bunga, tiket perjalanan, fasilitas penginapan, perjalanan wisata, pengobatan CumaCuma, dan fasilitas lainnya. Gratifikasi tersebut baik yang diterima di dalam maupun di luar negeri dan yang dilakukan dengan menggunakan sarana elektronik atau tanpa sarana elektronik. 
b. Pelaku tindak pidana korupsi.

Bahwa pelaku tindak pidana korupsi yang masuk dalam lingkup kewenangan KPK adalah :

Pertama. Setiap orang yang memenuhi syarat sebagaimana dimaksud pasal-pasal dalam Undang-Undang Nomor : 20 tahun 2001 tentang perubahan atas Undang-Undang Nomor : 31 Tahun 1999 tentang Pemberantasan Tindak Pidana Korupsi.

Kedua. Adalah setiap orang yang memenuhi Pasal 11 Undang-Undang Nomor : 30 Tahun 2002 tentang Komisi Pemberantasan Tinak Pidana Korupsi, sebagaimana telah diuraikan tersebut di atas. Di luar ketentuan Pasal 11 tersebut adalah menjadi kewenangan Penyidik Polri dan Penyidik Kejaksaan.

Menurut Teori hukum progresif menurut Prof. Satjipto Rahardjo menegaskan bahwa hukum adalah untuk manusia, dan bukan sebaliknya. Selanjutnya disebutkan bahwa "Hukum itu bukan hanya bangunan peraturan, melainkan juga bangunan ide, kultur, dan cita-cita". Oleh karena itu, pemikiran hukum perlu kembali pada filosofis dasarnya, yaitu hukum untuk manusia. Dengan filosofis tersebut, maka manusia menjadi penentu dan titik orientasi hukum. Hukum bertugas melayani manusia, bukan sebaliknya. Dengan demikian, hukum itu bukan merupakan institusi yang lepas dari kepentingan manusia. Mutu hukum ditentukan oleh kemampuannya untuk mengabdi pada kesejahteraan manusia. Ini menyebabkan hukum progresif menganut "ideologi" : Hukum yang Pro-Keadilan dan Hukum yang Pro-Rakyat.
Dalam logika itulah revitalisasi hukum dilakukan setiap kali. Bagi hukum progresif, proses perubahan tidak lagi berpusat pada peraturan, tetapi pada kreativitas pelaku hukum mengaktualisasikan hukum dalam ruang dan waktu yang tepat. Para pelaku hukum progresif dapat melakukan perubahan dengan melakukan pemaknaan yang kreatif terhadap peraturan yang ada, tanpa harus menunggu perubahan peraturan (changing the law). Peraturan buruk tidak harus menjadi penghalang bagi para pelaku hukum progresif untuk menghadirkan keadilan untuk rakyat dan pencari keadilan, karena mereka dapat melakukan interprestasi secara baru setiap kali terhadap suatu peraturan. Untuk itu agar hukum dirasakan manfaatnya, maka dibutuhkan jasa pelaku hukum yang kreatif menterjemahkan hukum itu dalam kepentingan-kepentingan sosial yang memang harus dilayaninya.

Berdasarkan teori ini, keadilan tidak bisa secara langsung ditemukan lewat proses logis formal. Keadilan justru diperoleh lewat institusi, karenanya argumen-argumen logis formal "dicari" sesudah keadilan ditemukan untuk membingkai secara yuridis-formal keputusan yang diyakini adil tersebut. Oleh karena itu konsep hukum progresif, hukum tidak mengabdi bagi dirinya sendiri, melainkan untuk tujuan yang berada di luar dirinya.

Dalam masalah penegakan hukum, terdapat 2 (dua) macam tipe penegakan hukum progresif :

1. Dimensi dan faktor manusia pelaku dalam penegakan hukum progresif. Idealnya, mereka terdiri dari generasi baru profesional hukum yang memiliki visi dan filsafat yang 
mendasari penegakan hukum progresif.

2. Kebutuhan akan semacam kebangunan di kalangan akademisi, intelektual dan ilmuan serta teoritisi hukum Indonesia.

\section{Metode Penelitian}

Dalam penulisan ini menggunakan metode penelitian sebagai berikut :

1.Metode Pendekatan

Metode pendekatan yang dipergunakan adalah metode pendekatan secara yuridis normatif, yaitu suatu penelitian yang dilakukan dengan cara meneliti bahan pustaka atau data sekunder belaka (Soekanto dan Sri Mahmuji Rahayu). Pendekatan yuridis adalah suatu pendekatan yang mengacu pada hukum / peraturan perundangundangan yang berlaku, teori hukum dan pendapat para sarjana (Romi;1983).

2. Spesifikasi Penelitian

Penelitian spesifik dilakukan melalui penelitian deskriptif, yaitu penelitian yang menggambarkan yuridis normatif atas penetapan tersangka dalam tindak pidana korupsi.

3. Metode Analisis Data

Dalam mencari dan mengumpulkan data yang diperlukan, akan diusahakan sebanyak mungkin data yang diperoleh berkenaan dengan masalah-masalah yang berhubungan dengan penelitian ini. Hal ini dilakukan dengan tujuan agar tidak terjadi penyimpangan dan pengaburan dalam pembahasan. Adapun data yang diperlukan dalam penulisan ini diperoleh melalui data primer. Data-data yang diperoleh tersebut selanjutnya merupakan landasan teori dalam melakukan analisis data serta pembahasan masalah.

\section{Pembahasan \\ Pengertian Gratifikasi.}

Arti gratifikasi menurut Penjelasan Pasal 12B UndangUndang Nomor 31 Tahun 1999 sebagaimana telah diubah dengan Undang-Undang Nomor 20 Tahun 2001 tentang Pemberantasan Tindak Pidana Korupsi ( UU Tipikor) adalah "Pemberian dalam arti luas", yakni meliputi pemberian uang, barang, rabat (discount), komisi, pinjaman tanpa bunga, tiket perjalanan, fasilitas penginapan, perjalanan wisata, pengobatan cuma-cuma, dan fsilitas lainnya. Gratifikasi tersebut baik yang diterima di dalam negeri maupun di luar negeri dan yang dilakukan dengan menggunakan sarana elektronik atau tanpa sarana elektronik.

1. Kriminalisasi.

Pengertian kriminalisasi dalam ilmu kriminologi bahwa kriminalisasi adalah sebuah proses saat terdapat sebuah perubahan perilaku individuindividu yang cenderung untuk menjadi pelaku kejahatan dan menjadi penjahat.

Pengertian kriminalisasi dalam hukum adalah proses yang memperlihatkan perilaku yang semula tidak dianggap sebagai peristiwa pidana, tetapi kemudian digolongkan sebagai peristiwa pidana oleh masyarakat.

Suatu perbuatan dinyatakan sebagai suatu pelanggaran hukum pidana hanya oleh suatu peraturan perundang-undangan, sebagaimana dimaksudkan oleh asas legalitas yang secara doktriner diturunkan dari adagium nulla poena sine lege; nulla poena sine crimine; nullum crimen sine poena legali, yang dalam perkembangannya kemudian "diringkas" menjadi adagium nullum 
delictum, nulla poena sine praevia lege punali, mengandung empat makna sebagai satu kebulatan pengertian, yaitu:

a. tidak ada perbuatan pidana dan karenanya tidak ada pidana jika tidak ada undang-undang yang telah mengatur sebelumnya (nullum crimen, nulla poena sine lege praevia) Dalam pernyataan ini terkandung pengertian bahwa norma hukum pidana tidak boleh berlaku surut atau retroaktif;

b. tidak ada perbuatan pidana dan karenanya tidak ada pidana jika tidak ada noma hukum tertulis atau undang-undang (nullum crimen, ulapoena sine lege scripta). Dalam pernyataan ini terkandung pengertian bahwa norma hukum pidana harus tertulis, demikian pula pidananya. Artinya, baik perbuatan yang dilarang maupun pidana yang diancamkan terhadap perbuatan yang dilarang itu harus tegas dituliskan dalam undang-undang;

c. tidak ada perbuatan pidana dan karenanya tidak ada pidana jika tidak ada aturan tertulis atau undang-undang yang jelas rumusannya (nullum crimen, nulla poena sine lege certa) Dalam pernyataan ini terkandung pengertian bukan hanya larangan untuk memberlakukan hukum tidak tertulis dalam hukum pidana dan dalam menjatuhkan pidana tetapi juga larangan menjatuhkan pidana jika rumusan norma dalam hukum tertulis (undang-undang) itu tidak jelas;

d. tidak ada perbuatan pidana dan karenanya tidak ada pidana jika tidak ada hukum tertulis yang ketat (nullum crimen, nulla poena sine lege stricta). Dalam pernyataan ini terkandung pengertian bahwa ketentuan yang terdapat dalam undang-undang pidana harus ditafsirkan secara ketat. Dari sini pula lahir pemahaman yang telah diterima di kalangan hukum bahwa dalam hukum pidana dilarang menggunakan analogi.

\section{Dekriminalisasi.}

Pengertian dekriminalisasi adalah penggolongan suatu perbuatan yang pada mulanya dianggap sebagai peristiwa pidana, tetapi kemudian dianggap sebagai perilaku biasa. Perbuatan sebagaimana dimaksud dalam pengertian diatas tidak memenuhi syarat sebagai perbuatan tindak pidana, sebagaimana syarat dalam asas legalitas.

\section{Gratifikasi Dalam Pandangan Masyarakat.}

Sebagaimana telah diuraikan dalam Bab Pendahuluan bahwa pemberian atau penerimaan yang terjadi di tengah-tengah masyarakat merupakan kebiasaan yang baik dan terlestarikan secara turun temurun hingga saat ini, meskipun hal tersebut mulai tergerus terutama di wilayah perkotaan, semakin tergerus ketika pemberian atau penerimaan gratifikasi tersebut dinyatakan sebagai suatu perbuatan yang dianggap suap dalam undangundang tipikor.

Masyarakat memaknai pemberian atau penerimaan gratifikasi yaitu tidak membedakan orang berikut statusnya, namun dalam undangundang tindak pidana korupsi membatasi gratifikasi yang dianggap suap hanya pada orang-orang tertentu yakni pegawai negeri atau penyelenggara. Dalam masyarakat yang terdiri dari kumpulan orangorang dengan tidak membedakan 
gratifikasi diberikan kepada siapa dan atau sebaliknya, namun gratifikasi diartikan mutlak sebagai pelaksanaan kebiasaan saling tolong atau bantu membantu.

Ketika seseorang menjalankan kebiasaan yang menurutnya baik (pemberian atau penerimaan) maka akan menjadi kontroversial ketika kebiasaan yang baik itu menjadi suatu pelanggaran hukum. Masyarakat menganggap bahwa pembatasan gratifikasi itu membutakan mata batin masyarakat untuk saling menolong atau membantu, meskipun gratifikasi tidak untuk semua orang. Karena bagaimana mungkin memisahkan pemberian atau penerimaan gratifikasi dengan keluarga atau sahabat atau apapun hubungan pemberi dan penerima, akan tetapi dirasakan cukup mencederai kekerabatan saling menolong.

Dari pembahasan singkat di atas, menjadi suatu masalah yang blunder di tengah-tengah masyarakat dan kriminalisasi gratifikasi tersebut menjadi sumber pencipta ketidak harmonisan di tengah-tengah kebiasaan yang baik. Pemberian atau penerimaan gratifikasi yang semula bukan merupakan perbuatan pidana, namun dalam UU Tipikor hal itu dikriminalisasi menjadi suatu perbuatan melanggar hukum atau dianggap perbuatan pidana, yang kemudian diatur 2 (dua) pasal, yaitu: 1. Pasal 12B, mengatur tentang ketentuan pidana.

a) Ayat (1).

Setiap gratifikasi kepada pegawai negeri atau penyelenggaraan negara dianggap pemberian suap, apabila berhubungan dengan jabatannya dan yang berlawanan dengan kewajiban atau tugasnya, dengan ketentuan sebagai berikut :

1) yang nilainya Rp.10.000.000,00 (sepuluh juta rupiah) atau lebih, pembuktian bahwa gratifikasi tersebut bukan merupakan suap dilakukan oleh penerima gratifikasi; 2) yang nilainya kurang dari Rp10.000.000,00 (sepuluh juta rupiah), pembuktian bahwa gratifikasi tersebut suap dilakukan oleh penuntut umum.

b) Ayat (2).

Pidana bagi pegawai negeri atau penyelenggaran negara sebagaimana dimaksud dalam ayat (1) adalah pidana penjara seumur hidup atau pidana penjara paling singkat 4 (empat) tahun dan paling lama 20 (dua puluh) tahun, dan pidana denda paling sedikit Rp 200.000.000,00 (dua ratus juta rupiah) dan paling banyak Rp 1.000.000.000,00 (satu milyar rupiah).

Pasal 12B tersebut menginstruksikan kepada masyarakat untuk memparsialkan kekerabatan dan menggerus rasa tolong menolong yang ada di tengah masyarakat. Pemberian atau penerimaan gratifikasi yang tulus telah membatasi jumlah yang akan diberi atau diterima dengan tidak melebihi jumlah yang dipersyaratkan dan tidak kepada kerabatnya yang berstatus pegawai negeri atau penyelenggara negara. Pegawai negeri atau penyelenggara negara merupakan anggota masyarakat yang berinteraksi dengan masyarakat lainnya tetapi tidak dalam hal memberi atau menerima gratifikasi, yang oleh karenanya kualitas hidup dalam sebuah interaksi menjadi samar-samar. 
2. Gratifikasi yang dianggap suap dalam Pasal 12B, namun gratfikasi bukan merupakan tindak pidana dinyatakan dalam Pasal 12C, yaitu mengatur tentang pelaporan dan tempus delicty gratifikasi, yaitu:

a. Ketentuan sebagaimana dimaksud dalam Pasal 12 B ayat (1) tidak berlaku, jika penerima melaporkan gratifikasi yang diterimanya kepada Komisi Pemberantasan Tindak Pidana Korupsi.

b. Penyampaian laporan sebagaimana dimaksud dalam ayat (1) wajib dilakukan oleh penerima gratifikasi paling lambat 30 (tiga puluh) hari kerja terhitng sejak tanggal gratifikasi tersebut diterima.

c. Komisi Pemberantasan Tindak Pidana Korupsi dalam waktu paling lambat 30 (tiga puluh) hari kerja sejak tanggal menerima laporan wajib menetapkan gratifikasi dapat menjadi milik penerima atau milik negara.

d. Ketentuan mengenai tata cara penyampaian laporan sebagaimana dimaksud dalam ayat (2) dan penentuan status gratifikasi sebagaimana dimaksud dalam ayat (3) diatur dalam Undang-undang tentang Komisi Pemberantasan Tindak Pidana Korupsi.

Kembali pada pandangan masyarakat terhadap kebiasaan tolong menolong dalam bentuk pemberian atau penerimaan gratifikasi tidak melihat pemebrian atau penerimaan gratifikasi yang tidak dinyatakan kiriminal atau didekriminalisasikan, namun pernyataan undang-undang tindak pidana korupsi dengan menegaskan perbuatan menerima ata memberi yang bukan dianggap sebagai suap tetap dirasakan sebagai suatu hal yang mencederai kebiasaan di tengah masyarakat, bahkan masyarakat yang senantiasa ingin melestarikan kebiasaan tolong menolong atau saling bantu berharap akan adanya kebijakan negara yang mendukungnya. Masyarakat tidak melihat maksud dan tujuan gratifikasi sebagai salah satu upaya untuk memberantas tindak pidana korupsi, karena masyarakat beranggapan bahwa pemberantasan tindak pidana korupsi masih banyak cara atau metoda lain yang dapat dilakukan.

Pemberantasan tindak pidana korupsi melalui metode gratifikasi yang dikriminalkan adalah sama urgentnya dengan melestarikan kebiasaan saling menolong atau membantu dalam bentuk gratifikasi. Kedua hal tersebut tidak dapat menegasikan satu dengan yang lain, tetapi harus pemberantasan tindak pidana korupsi harus berjalan seiring dengan kebiasaan masyarakat dalam hal saling membantu.

3. UU KPK No. 30 Tahun 2002, mengatur Tata Cara Pelaporan dan Penentuan Status Gratifikasi, dalam 3 (tiga) pasal, yaitu:

a. Pasal 16.

Setiap pegawai negeri atau penyelenggara negara yang menerima gratifikasi wajib melaporkan kepada Komisi Pemberantasan Korupsi, dengan tata cara sebagai berikut :

1) Laporan disampaikan secara tertulis dengan mengisi formulir sebagaimana ditetapkan oleh Komisi Pemberantasan Korupsi dengan melampirkan dokumen yang berkaitan dengan gratifikasi.

2) Formulir sebagaimana dimaksud pada huruf a sekurangkurangnya memuat : 
a) nama dan alamat lengkap penerima dan pemberi gratifikasi;

b) jabatan pegawai negeri atau penyelenggara negara;

c) tempat dan waktu penerimaan gratifikasi;

d) uraian jenis gratifikasi yang diterima; dan

e) nilai gratifikasi yang diterima.

b. Pasal 17.

1) Komisi Pemberantasan Korupsi dalam waktu paling lama 30 (tiga puluh) hari kerja terhitung sejak tanggal laporan diterima wajib menetapkan status kepemilikan gratifikasi disertai pertimbangan.

2) Dalam menetapkan status kepemilikan gratifikasi sebagaimana dimaksud pada ayat (1) Komisi Pemberantasan Korupsi dapat memanggil penerima gratifikasi untuk memberikan keterangan berkaitan dengan penerimaan gratifikasi.

3) Status kepemilikan gratifikasi sebagaimana dimaksud pada ayat (1) ditetapkan dengan keputusan Pimpinan Komisi Pemberantasan Korupsi.

4) Keputusan Pimpinan Komisi Pemberantasan Korupsi sebagaimana dimaksud pada ayat (3) dapat berupa penetapan status kepemilikan gratifikasi bagi penerima gratifikasi atau menjadi milik negara.

5) Komisi Pemberantasan Korupsi wajib menyerahkan keputusan status kepemilikan gratifikasi sebagaimana dimaksud pada ayat (4) kepada penerima gratifikasi paling lambat 7 (tujuh) hari kerja terhitung sejak tanggal ditetapkan.
6) Penyerahan gratifikasi yang menjadi milik negara kepada Menteri Keuangan, dilakukan paling lambat 7 (tujuh) hari kerja terhitung sejak tanggal ditetapkan.

c. Pasal 18

Komisi Pemberantasan Korupsi wajib mengumumkan gratifikasi yang ditetapkan menjadi milik negara paling sedikit 1 (satu) kali dalam setahun dalam Berita Negara. Mencermati ketentuan-ketentuan tentang gratifikasi sebagaimana dijelaskan di atas, Penulis berpendapat bahwa:

a. Dalam kaitan gratifikasi dengan budaya bangsa Indonesia bahwa pemberian gratifikasi tidak selamanya dikaitkan dengan jabatan atau kewajiban atau tugas penerima, akan tetapi pemberian gratifikasi umumnya karena ikatan kekeluargaan - persaudaraan atau sahabat - dan lain-lain.

Suatu hal yang dapat dikatakan agak aneh atau bertentang dengan rasa keadilan masyarakat, misalnya penerimaan gratifikasi saat pesat uang tahun, berupa kue tart atau makanan lain yang nilainya melampaui Rp. 10.000.000,00 (sepuluh juta rupiah) dan menurut undang-undang penerimaan tersebut harus dilaporkan kepada KPK dengan maksud agar tidak terkena pasal tindak pidana korupsi, untuk kemudian KPK memutuskan apakah kue tart atau makanan tersebut milik penerima atau milik negara. Sedangkan diketahui secara logika bahwa kue tart atau makanan memiliki kadaluarsa yang singkat. Terhadap hal seperti ini tentu akan melahirkan pertanyaan, salah satunya adalah "Bagaimana KPK 
memandang persoalan seperti ini untuk menjawab rasa keadilan masyarakat dihadapkan dengan keadilan berdasarkan UU Tipikor?

b. Dalam hal menetapkan status gratifikasi.

KPK akan kesulitan atau bahkan tidak mungkin dapat mengetahui atau menentukan yang mana diantara sejumlah jenis gratifikasi, apakah gratfikasi jenis ini atau jenis itu berhubungan dengan jabatannya atau berlawanan dengan kewajibannya atau tugasnya penerima gratifikasi dalam rangka menetapkan status gratifikasi, yaitu menjadi milik penerima atau milik negara. Demikian juga dalam proses penentuan, misalnya sejumlah amplop berisi uang dalam sebuah peti yang diberikan atau disumbangkan oleh orang yang diundang dalam pesta, sedangkan amplop-amplop tersebut ada yang diberi identitas dan ada yang tidak beridentitas (nama, pekerjaan, dan alamat). Bagaimana KPK menetapkan berapa amplop atau jumlah uang yang akan ditetapkan menjadi milik penerima atau milik negara.

Peluang untuk salah cukup besar dalam KPK menetapkan status gratifikasi, yang tentunya akan berdampak pada adanya rasa kecewa terhadap tercederainya budaya bangsa Indonesia. Pada tataran penentuan pemberian atau penerimaan gratifikasi tidak terlalu penting bagi masyarakat, tapi yang terpenting adalah bagaimana hubungan masyarakat dalam interaksinya yang saling hormat menghormati atau saling tolong menolong atau bantu membantu. Pemberian atau penerimaan sesuatu tidaklah selamanya dianggap KPK mampu mengimplementasikannya dengan tidak merugikan pihak-pihak.

\section{Kesimpulan.}

1. Penerimaan atau pemberian gratifikasi dinyatakan sebagai suatu perbuatan kriminal atau melanggar hukum pidana sebagaimana dalam undangundang tindak pidana korupsi, sekaligus membatasi gratifikasi mana yang bukan melanggar hukum pidana, dengan maksud dan tujuan sebagai salah satu upaya dalam pemberantasan tindak pidana korupsi di Indonesia. Namun demikian, masyarakat memandang pemberian atau penerimaan gratifikasi merupakan salah satu sumber pencederaian dari kebiasaan masyarakat yang saling tolong menolong atau bantu membantu. Selain itu bahwa masyarakat justru berkehendak melestarikan kebiasaan saling tolong atau bantu tersebut karena diyakini kebiasaan itu merupakan suatu hal yang baik.

2. Realitas dalam masyarakat bahwa pernyataan dekriminalisasi terhadap suatu perbuatan pemberian atau penerimaan gratifikasi sama nilainya dalam pencederaian kebiasaan baik yang telah berjalan, karena sesuatu yang diberikan atau diterima harus melalui proses pemeriksaan atau penilaian oleh KPK. Hasil akhir dari penetapan gratifikasi itu tidak menjadi urgen dalam masyarakat, tetapi proses pemeriksaan merupakan suatu perlakuan yang tidak beretika. 
3. Mengingat benda-benda atau sesuatu dalam pemberian atau penerimaan gratfikasi tidak dibatasi, maka pemberian atau penerimaan dalam bentuk makanan atau minuman yang nota bene memiliki kadaluarsa akan menjadi busuk tidak berguna karena harus menjalani proses pemeriksaan (pembuktian) dan penilaian. Dengan demikian, penerima atau pemberi gratifikasi dalam bentuk makanan dan minuman akan menuai kekecewaan. KPK bertindak melakukan proses pembutkain atau penilaian terhadap makanan dan minuman dirasakan hanya mementingkan maksud dan tujuan pemberantasan tindak pidana korupsi tanpa mempertimbangkan aspek lain yang dibutuhkan oleh masyarakat.

Saran.

1. Pemberantasan tindak pidana korupsi melalui upaya pengkriminalan pemberian atau penerimaan gratifikasi patut untuk dipertimbangkan kembali dalam Rancangan UndangUndang atau RKUHP, mengingat upaya pemberantasan tindak pidana korupsi masih terdapat banyak cara atau metode lain.

2. Pemberantasan tindak pidana korupsi dalam RKUHP tentang pemberian atau penerimaan gratifikasi hendaknya tidak mencederai kebiasaan masyarakat dalam hal tolong menolong atau bantu membantu.

\section{Daftar Pustaka}

Pedoman Pengendalian Gratifikasi.

Panduan Penanganan Konflik Kepentingan dapat diunduh pada:

(http://kpk.go.id/grati fikasi/images/pdf/KonflikK. pdf).

Soerjono, Soekanto. 2007. Pengantar Penelitian Hukum Cetakan 3. Universitas Indonesia pres: Jakarta.

Soerjono Soekanto dan Sri Mahmuji Rahayu,Penelitian Hukum Normatif Suatu Tinjauan Singkat, Jakarta: PT Raja Grafindo Persada, (2004).

Romi Hanitijo Soemitro, Metodologi Penelitian Hukum dan Jurismetri, Jakarta: Ghalia,(1983).

Undang-Undang Nomor 28 Tahun 1999 tentang

Penyelenggaraan Negara yang Bersih dan Bebas dari Korupsi, Kolusi dan Nepotisme.

Undang-Undang Nomor 20 Tahun 2001 tentang Perubahan Undang-Undang Nomor 31 Tahun 1999 Tentang Pemberantasan Tindak Pidana Korupsi.

Undang-Undang Nomor 2 Tahun 2002 tentang Kepolisian Negara Republik Indonesia.

Undang-Undang Nomor 30 Tahun 2002 tentang Komisi Pemberantasan Tindak Pidana Korupsi.

Undang-Undang Nomor 7 Tahun 2006 tentang Konvensi Perserikatan Bangsa-Bangsa Anti Korupsi, 2003 (Pengesahan United Nation Convention Against Corruption, 2023). 
https:/ / www.hukumonline.com/ber ita/baca/lt536a12d6bfa9b/gr atifikasi-marak-karena-

budaya-indonesia-mirip- amerika-serikat diakses 21 Mei 2019. 